\title{
The evolution of the Uppsala model: Towards non-linearity of internationalization of firms ${ }^{1}$
}

\author{
Krzysztof Wach
}

\section{A B S T R A C T}

Objective: The objective of the article is to synthesize the process of transforming the Uppsala model of internationalization of the firm from the original one of 1977 to the most up-to-date model of globalization of 2017.

Research Design \& Methods: This article is based on a literature review - primary sources presenting the concepts of Johanson and Vahlne as the authors of the Uppsala models.

Findings: This article discusses a total of seven models proposed by Johansson and Vahlne (in the years 1977, $2009,2010,2011,2013,2014,2017)$ with their various smooth extensions $(1990,2003,2006,2012)$ showing the way they were transformed and evolved.

Implications \& Recommendations: Although stages models are often criticized in the literature, they are still widely used in empirical research. Their successive modifications may attest to their universal character and timelessness.

Contribution \& Value Added: The article compiles all the major models from Johanson and Vahlne, and sometimes also of their co-authors (Ivarsson and Schweizer), in one place, showing their common base and differentiating issues that differ in these models.

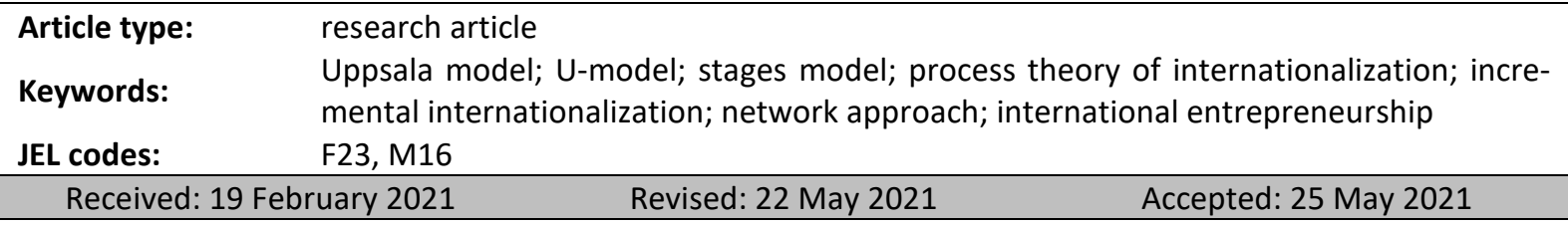

Suggested citation:

Wach, K. (2021). The evolution of the Uppsala model: Towards non-linearity of internationalization of firms. International Entrepreneurship Review, 7(2), 7-19. https://doi.org/10.15678/IER.2021.0702.01

\section{INTRODUCTION}

The roots of stages models date back to the 1970s when, almost simultaneously, Swedish and Finnish researchers used the behavioural theory of the firm to explain the internalization behaviour. This group of theories is also referred to as Nordic models (Ruzzier, Hisrich \& Antoncic, 2006, p. 482), or learning models (Ibidem), but also process models (Mejri \& Umemoto, 2010, p. 157), incremental models (Coviello \& McAuley, 1996; Rundh, 2001, p. 319), sequential models (Wickramasekera \& Oczkowski, 2006, p. 52), establishment chain models (Crick, Chaudhry, \& Batstone, 2001, p. 79), gradual theories (Morgan \& Katsikeas, 1997, p. 72), evolutionary theories (Ibidem), or process theories of internationalization (PTI) (Schwens, Steinmetz, \& Kabst, 2010, p. 114) or just the Swedish school. They are based on the phase (process) convention of corporate growth and development. Their common feature is the sequential passage in the internationalization process through individual stages or phases, which together create a specific established order, and each subsequent stage is associated with greater involvement of the firm in international activities. Ruzzier, Hirsrich and Antoncic (2006, p. 482) distinguished two basic stages models, which are most often referred to in the literature, namely the Uppsala model (U-model) and the innovation-related model (I-model) (Wach, 2016a).

\footnotetext{
${ }^{1}$ This is an extended version of the previous article published in the Polish language: (Wach, 2017).
} 
The origins of the stages models of firm-level internationalization date back to the mid-1970s and are associated with Swedish researchers working in Uppsala; hence the models, they proposed, are referred to as the Uppsala models or U-models. "Internationalization - according to the process view - is a process of increasing commitments to foreign operations" (Johanson \& Vahlne, 2003, p. 90).

The original Uppsala model was subsequently developed by numerous authors; hence there are many hybrid models in the literature, especially in the extant literature from the 1980s and 1990s. Recently, Johanson and Vahlne, as the original authors of this model, have proposed several modifications of their theoretical concept, and there are at least six such revised models of their authorship in the literature (not to mention a couple more minor extensions of the U-model). Subsequent models were a response to emerging criticism and thus took into account newer theoretical approaches and frameworks developed later in the literature.

This article aims to synthetically discuss the transformation process of the Uppsala model of the firm-level internalization from the original 1977 model to the most recent the Uppsala model of 2017. The article consists of four parts. The first part of this article describes the research methodology, including selecting reference sources. The second, main part, of this article undertakes a conceptual review of the literature. The third part elaborates on the critics of stages models. The fourth, final part of this study, summarises the whole article.

\section{MATERIAL AND METHODS}

This article is based on a literature review - primary sources presenting the concepts of Jan Johanson and Jan-Erik Vahlne as the authors of the Uppsala models. This article discusses a total of seven models proposed by Johansson and Vahlne (in the years 1977, 2009, 2010, 2011, 2013, 2014, 2017), sometimes also with their co-authors (Ivarsson and Schweizer), with their various smooth extensions (1990, $2003,2006,2012$ ) showing the way they were transformed and evolved. The article elaborates on the available extant literature and desk research. This article uses a qualitative design of research based on a cause-effect analysis, along with predictive synthesis, modelling, induction, and description of the synthetic and the critic literature review. This study is descriptive, making use of a comparative analysis technique.

\section{LITERATURE REVIEW}

\section{The Primary Uppsala Model of 1977}

Johanson and Vahlne $(1974 ; 1977)$ are the authors of the Uppsala model, although Wiedersheim-Paul also contributed to the development of this model (Johanson \& Wiedersheim-Paul, 1975). The internationalization of firms, in particular small and medium-sized enterprises is treated as an incremental process of international engagement as a result of the learning process, while incrementality is understood as a consequence of a series of decisions. This model assumes a stepwise expansion in four stages (Johanson \& Wiedersheim-Paul, 1975, p. 307):

1. No regular export activity;

2. Exports via independent representatives (agents);

3. Foreign sales subsidiaries;

4. Foreign production/manufacturing subsidiaries.

These four steps are related to the greater involvement of resources leading to different market experience and market knowledge. The first stage is manifested by the fact that the firm does not commit its resources to export activities, which means that it is not possible to obtain the required knowledge about foreign markets. The second stage, on the contrary, allows the firm to obtain regular information about foreign sales markets, which of course, is related to market involvement. The third stage is related to a controlled information channel that allows the firm to obtain information from the market. This stage also allows gaining direct experience about the resource factors determining the further internationalization process. Finally, the fourth stage means even more resource involvement. Johanson and 
Vahlne refer to this sequence or the order of the development operations of the firms in individual countries as an establishment chain.

Johanson and Vahlne, expanding the model, made it more detailed by dividing the factors into state and change aspects (static/constant and dynamic variables). The essence of the model (Figure 1) is therefore the state of internationalization, mathematically defined as $\Delta \mathrm{I}=\mathrm{f}(\mathrm{I}$...). Input constant variables (market knowledge and market commitment) influence dynamic variables (commitment decisions and current activity). The level of internationalization depends on the accompanying risk (Johanson \& Vahlne, 1977, p. 30), written mathematically as:

$$
R_{i}=C_{i}+U_{i}
$$

where:

$R_{i}$ - existing market risk situation on $i$ market;

$C_{i}$ - existing market commitment;

$U_{i}$ - existing market uncertainty.

As a result of the dynamic step-by-step process, there is an increase in risk $\left(\Delta R_{i}\right)$. The scale of further internationalization will therefore be limited by the market commitment $\left(\Delta R_{i}=U_{i} \cdot \Delta C_{i}>\right.$ 0 ), while decisions themselves will be limited by uncertainty according to the formula $\Delta R_{i}=\Delta U_{1}$. $\left(C_{i}+\Delta C_{i}\right)+\Delta C_{i} \cdot U_{1}<0$.

Forsgren (2015) underlines that that lack of knowledge about foreign markets is a significant obstacle to international operations. Still, such knowledge can be acquired by a firm, which is a centre point and assumption of the Uppsala model.

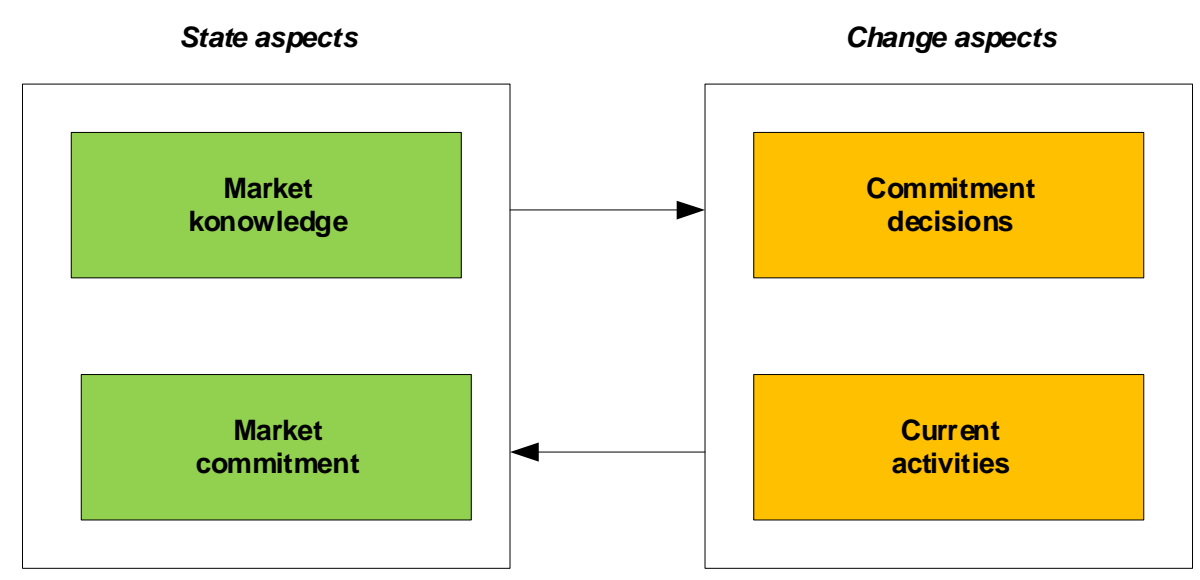

Figure 1. Original Uppsala model of 1977

Source: (Johanson \& Vahlne, 1977, p. 26; 1990, p. 12).

The Network Uppsala Model of 2009

Meanwhile, Johanson and Vahlne $(1990 ; 2003,2006)$ proposed three extensions of their original model. Johanson and Vahlne (2003) underscored that institutional, economics and cultural barriers (literally fences as they called them), which are usually discussed in terms of psychic distance and cultural distance, are based on the country-market specifics. Therefore, a business network model of internationalization might be helpful especially while explaining international new ventures. Instead of country markets, it is necessary to focus on relationship building with customers or supplier firms in the widely understood international business environment (Wach, 2016b; Głodowska, Pera \& Wach, 2016).

Johanson and Vahlne (2009) proposed a modified version of their stages model from 1977 (a major revision), adapting it to the network approach (Figure 2). This model assumes that the firm is embedded in an active network of interdependent actors. As in the original model, it contains four interrelated variables, two constants aspects related to knowledge storage and two dynamic variables related to knowledge flow. These variables condition a dynamic cumulative learning process, but also the firm's commitment to trust (Johanson \& Vahlne, 2009, p. 1423). An increasing level of knowledge has a positive 
or negative impact on trust building. In relation to the original model, an important change is the introduction of the entrepreneurial theory primer manifested in recognition of opportunities to the knowledge. These opportunities constitute knowledge, constituting its subset, alongside needs, competences, strategies and network relations (Johanson \& Vahlne, 2009, p. 1424). As the internationalization process occurs within a network, the variable 'market commitment' from the original model was replaced by the variable 'network position', as network relations condition the internationalization process. As one of the two dynamic variables, learning by building trust expresses the outcome of current activities. Therefore, it contributes to an increase in knowledge. The last variable of the model was only supplemented in relation to the original concept with the attribute 'relational' to emphasize the key role of networks in the decision-making process (relationship commitment decisions).

The Network Uppsala Model of 2009 was announced the article of the decade and received the JIBS Decade Award (Verbeke, 2020).

State aspects

Change aspects

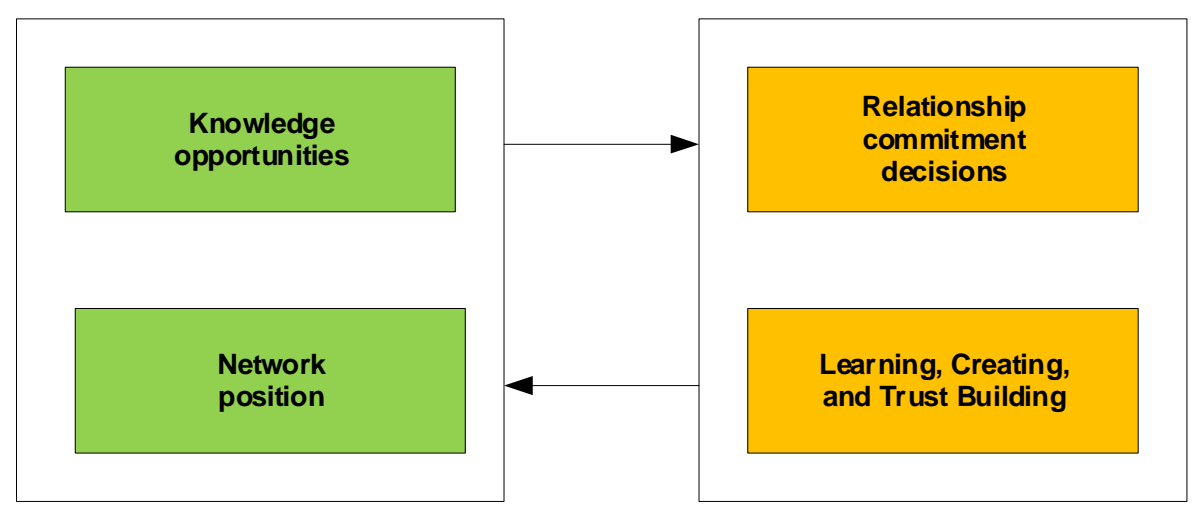

Figure 2. Network Uppsala Model of 2009

Source: (Johanson \& Vahlne, 2009, p. 1424).

\section{The Entrepreneurial Uppsala Model of 2010}

International entrepreneurship (IE), initiated and developed in the 1990s, has been blooming in the international business literature since the 2000s (Wach, 2015a, 2015b, 2015c; Głodowska, 2019; Głodowska, Maciejewski \& Wach, 2019a, 2019b; Maciejewski \& Wach, 2019).

One of the proofs of the growing popularity of international entrepreneurship models is the third, in chronological terms, modification of the Uppsala model $(1977,2009,2010)$, which is an attempt to operationalize the model of 2009 (Figure 3). The modification consists of implementing entrepreneurship theory, at a relatively detailed level, which places this model undoubtedly in the international entrepreneurship approach in the international business research.

The modified model is worth focusing only on the latest changes. The overall concept is based on the 2009 model. These elements are not discussed again as they have already been discussed above. The dynamic variables have been extended by a new one - the use of contingencies ${ }^{2}$ - which are not necessarily related to each other as they result from the nonlinear dynamics of the environment. Schweizer, Vahlne and Johanson (2010, p. 365), as the authors of this revision, underscore that the model's dynamics is two-sided, the static and dynamic variables interact. Strategic decisions lead the firm into unknown markets, which are characterized by Knightian uncertainty. High uncertainty forces firms to engage incrementally in new markets, with beneficial engagement as uncertainty levels are expected to decrease. Entrepreneurial sensitivity causes firms to observe their environment, as radical changes in the environment can increase the level of uncertainty. Experiential learning occurs between

\footnotetext{
2 The theory of entrepreneurship very often refers to contingencies, which is a reference to the philosophical theory of contingentism. These are the entrepreneur, the market opportunity, the organisation of the enterprise and the resources. Between these variables there are interactions, but not based on necessity, but on the human subjectivity that characterises the entrepreneur. These interactions are the essence of the entrepreneurial process (Wickham, 2006, p. 223).
} 
networked firms, and as trust and relationships increase, they engage together in the internationalization process. However, this can result in a two-part relationship in which partner firms lose their independence due to mutual adjustment, leading to mutual control. Two-partner relationships intensify cooperation in the network, as the establishment of cooperation by one partner entails the other partner.

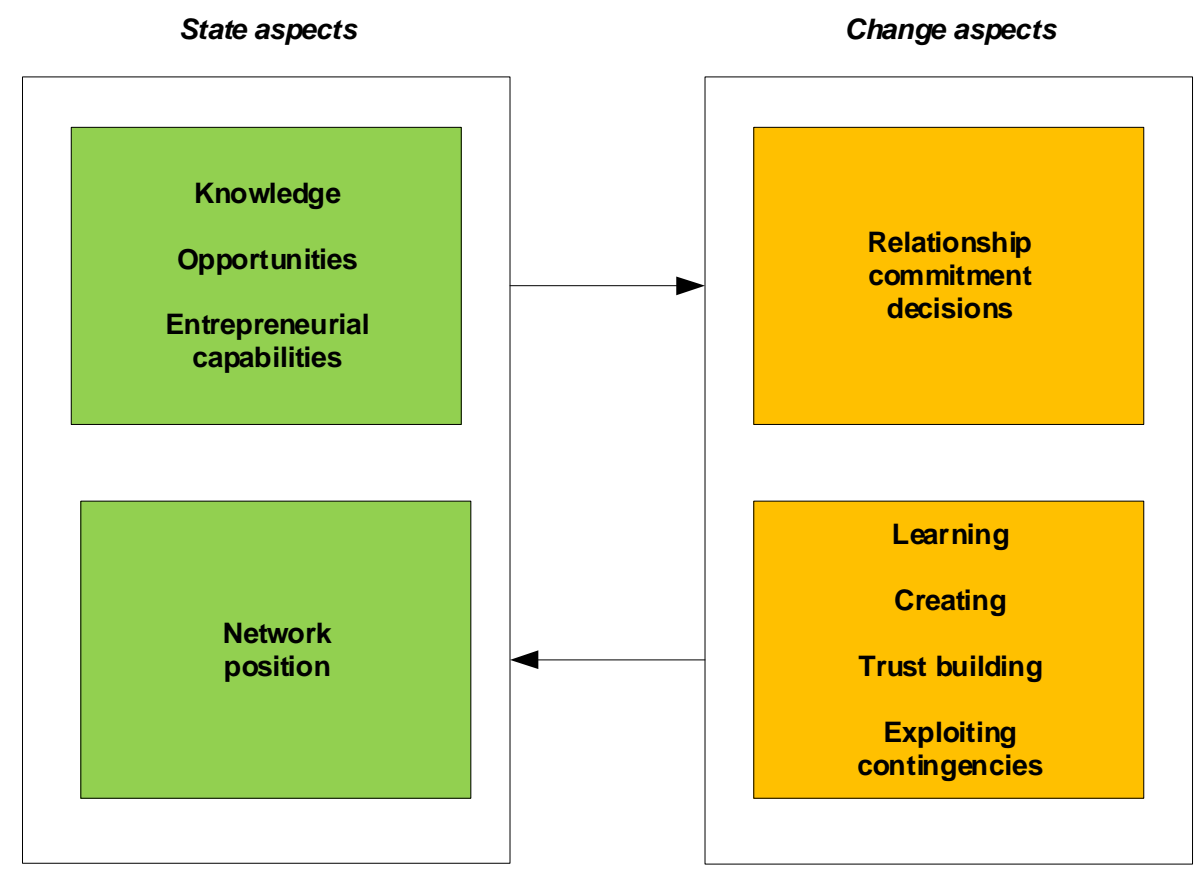

Figure 3. Entrepreneurial Uppsala Model of 2010

Source: (Schweizer, Vahlne \& Johanson, 2010, p. 365).

The static variables have also been modified. Both tangible and intangible resources are included in the analysis, and knowledge is understood here as the entrepreneurial knowledge and organizational knowledge. Knowledge and the ability to discover market opportunities is the engine that drives the entrepreneurial process, which is the key element of the model from the entrepreneurial perspective. Schweizer, Vahlne and Johanson $(2010$, p. 346) emphasize the crucial role of identifying market opportunities as the quintessence of entrepreneurship. In the model, this factor is treated as recognition of the value of new information and ideas, which often occurs accidentally (accidental discovery) in the sense of Kirzner. The mechanism of the other two variables is analogous to the previous model, although they are explained in the stream of entrepreneurship theory.

The decision-making process underlying relational decision-making commitment is expressed in the dynamic variable 'relationship commitment decision' (Schweizer, Vahlne, \& Johanson, 2010, p. 347). This is considered through the concept of effectuation as opposed to causation (Pawęta, 2016). The concept of effectuation process was introduced into entrepreneurship theory by Sarasvathy $(2001)^{3}$ and further developed together with Drew (Drew \& Sarvasvathy, 2002). The entrepreneur is identified in this concept with the effectuator. The perspective of the effectuation process, originally developed to explain the mechanism of new venture formation, has been used by the authors of the Uppsala entrepreneurial model to analyze the decision-making process regarding the internationalization of a networked firm (Schweizer, Vahlne, \& Johanson, 2010, p. 347). The modified model also uses

\footnotetext{
${ }^{3}$ According to Sarasvathy (2001, p. 245) effectuation processes use a set of given means and focus on the choice between possible effects that can be created from that set of means. In other words, it is therefore a set of entrepreneurial decision rules that can be applied in situations of uncertainty. In contrast, causation processes use a given partisan effect and focus on choosing between the means of creating that effect, which, in simple terms, describes decision-making using heuristic methods rooted in forecasting.
} 
the entrepreneurial concept of dynamic capabilities as a strategic and organizational process that creates value in dynamic markets by appropriately transforming resources into new value-creating strategies (Schweizer, Vahlne, \& Johanson, 2010, p. 349).

Vahlne, Schweizer and Johanson (2012) developed also the extension of this model focusing on the network position and eliminating entrepreneurial contingencies.

\section{The First Globalization Uppsala Model of 2011: Network Coordination}

Due to the growing popularity of globalization processes in the economy, and especially the global dimension of business in the 1980s and 1990s, Vahlne, Ivarsson and Johanson (2011) decided to develop the Uppsala variant of the firm globalization process, in which the globalization is understood as an attempt to optimize business operations in terms of configuration and coordination of systems, where configuration refers to the design of the value chain and coordination relates to the interdependencies between the different units of a given firm operating in the global market. The process of globalization of the firm is understood here as an intricate path to a global firm, while the process of internationalization is understood here as the transition from a national to an international firm, and then to a multinational enterprise (Vahlne, Ivarsson \& Johanson, 2011, p. 2).

This revised Uppsala model is built on the assumptions of previous models (1977, 2009, 2010 and their extensions), especially the network approach and the entrepreneurial process of identifying and exploiting market opportunities. Three variables (two static and one dynamic ones) are unchanged and carried over from the previous version of the model. In addition, a new dynamic variable is introduced - reconfiguration and coordination, which is a typical feature of the firm globalization process (Vahlne, Schweizer, \& Johanson, 2012). The degree of globalization of the firm increases due to the implementation of reconfiguration decisions and actions and the change of coordination within the firm and its subordinate units (Figure 4).

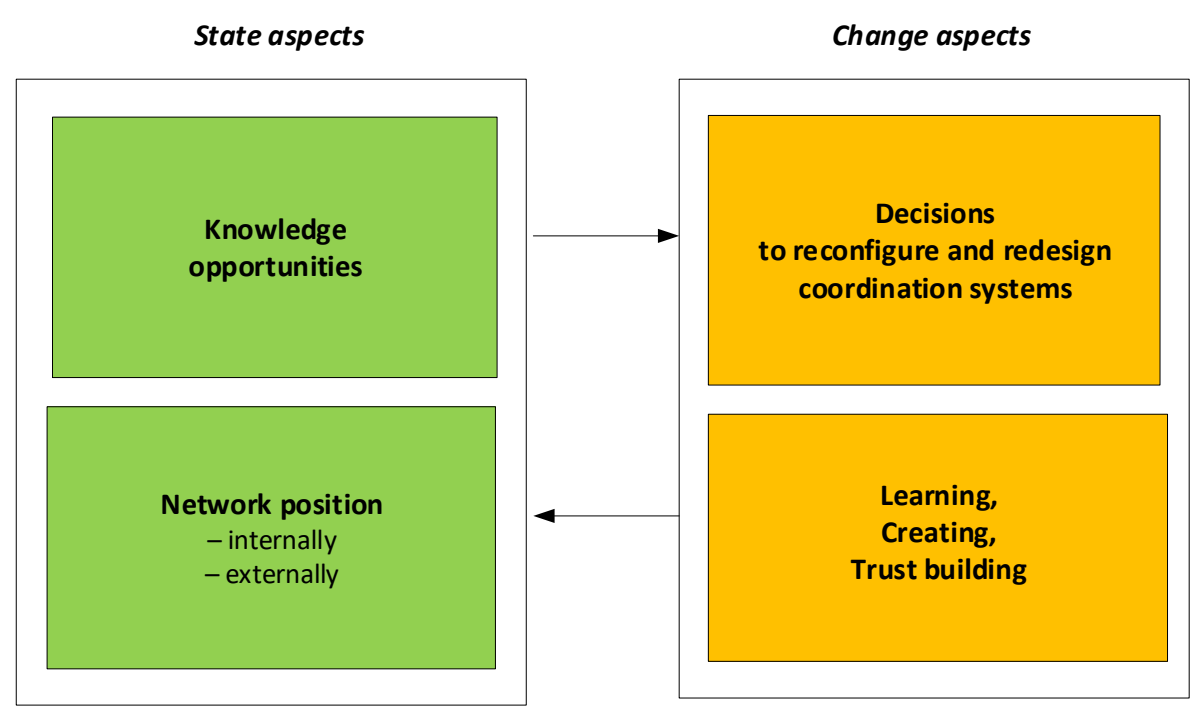

Figure 4. First Globalisation Uppsala Model of 2011

Source: (Vahlne, Ivarsson, \& Johanson, 2011, p. 3).

\section{The First Multinational Uppsala Model of 2013}

In response to the criticism that the Uppsala model does not incorporate the assumptions of Dunning's OLI theory, which is the dominant paradigm in the business theory focusing on explaining the internalization processes of transnational corporations, Johanson and Vahlne (2013) proposed a revised Uppsala model to explain the evolution of multinational enterprises (multinational business enterprise, $M B E$ ). The model is dynamic in nature as it is based on the knowledge that is either acquired as a result of the learning process or is created. In this model, the two dynamic variables (Figure 5) basically remain as in the previous model. In addition, the static variables are modified. The model is based on the concept of dynamic capabilities, of which three key dynamic capabilities for the internationalization 
process have been identified and selected. The first is identifying entrepreneurial opportunities and the mobilization of appropriate resources both in own firm and in other firms involved in these opportunities (Johanson \& Vahlne, 2013, p. 202). The second key capability is the development of different markets and locations in different considerations, which is called internationalization capability. The second variable, network position, is slightly modified. The position can also be described in terms of the degree of multinationality or globalness. In effect, the network position depends on the strength of the relationships between network partners.

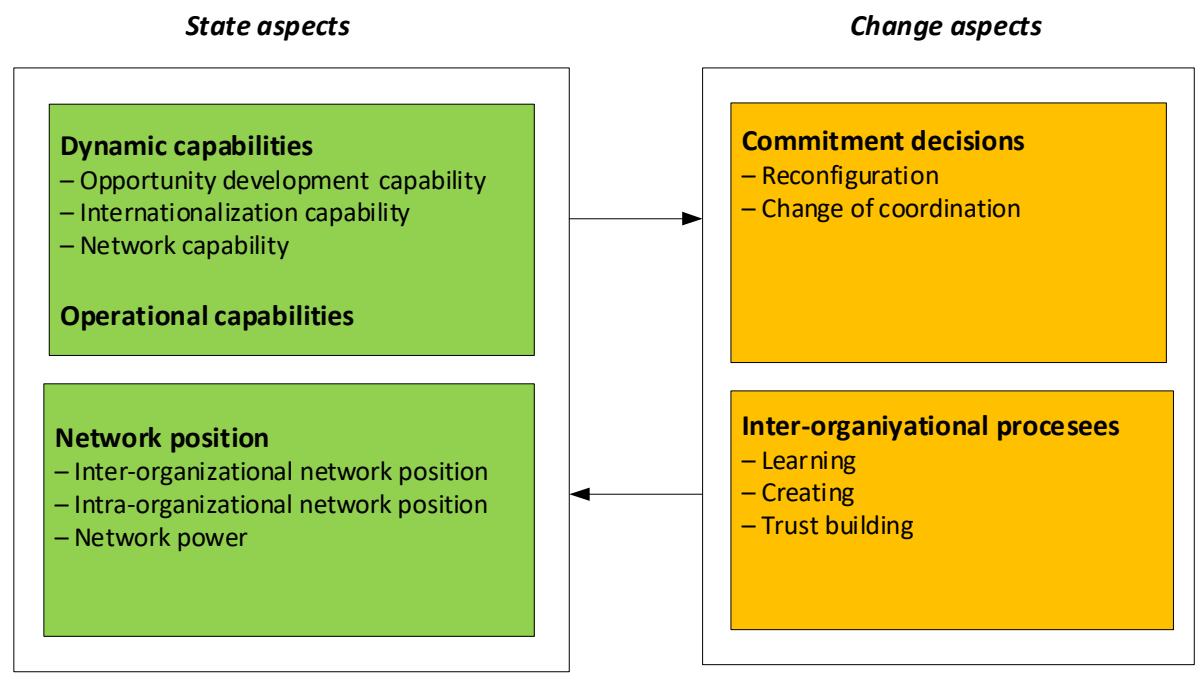

Figure 5. First Multinational Uppsala Model of 2013 Source: (Johanson \& Vahlne 2013, p. 200).

\section{The Second Globalization Uppsala Model of 2014: Full Globalization and Performance}

A further update of the Uppsala model of 2014 attempts to engage all previous approaches, including the network approach, international entrepreneurship perspective, high-tech and innovation perspectives, which are combined as a developed view of the role of resources sensu largo, placed in the model as variables called operational capabilities and dynamic capabilities (Figure 6). The learning process and knowledge-based models are expressed in the variable 'organizational processes'. Vahlne and Ivarsson (2014, pp. 227-247) built their model on the original model from the 1970s. The revised model is based on the original model from the 1970s (Johanson \& Vahlne, 1977) and four subsequent modifications taking into account the network approach (Johanson \& Vahlne, 2009), international entrepreneurship theory (Schweizer, Vahlne \& Johanson, 2010; Vahlne, Schweizer \& Johanson, 2012) as well as international network coordination (Vahlne, Ivarsson, \& Johanson, 2011; Vahlne \& Johanson, 2013) and the concept of multinational enterprises (Johanson \& Vahlne, 2013). This is the second globalization Uppsala model, referred to by the authors as The Uppsala Globalization Process Model of the Firm. For the first time, the model includes the outcomes of the internationalization-globalization process, referred to as the degree of globalization.

\section{The Second Multinational Uppsala Model of 2017}

Johanson and Vahlne (2017) extended the model once more, however, the structure and general content remained as in the original model developed in 1977 with two state and two change variables and the relationships between them (Figure 7). The business context is rooted in the network view; the focal point of the model is the multinational business enterprise (MBE).

The static variables include capabilities and commitments / performance. Capabilities, understood as firm-specific advantages (FSAs), include operational and dynamic capabilities as in previous models. Commitments describe resources distribution among the multi-business enterprise, such as product lines, scope of countries, and/or relationships between various unities of the enterprise. Performance 
is understood as multi-folded, for example, as the position in the network, degree of globalization or any other performance outcomes.

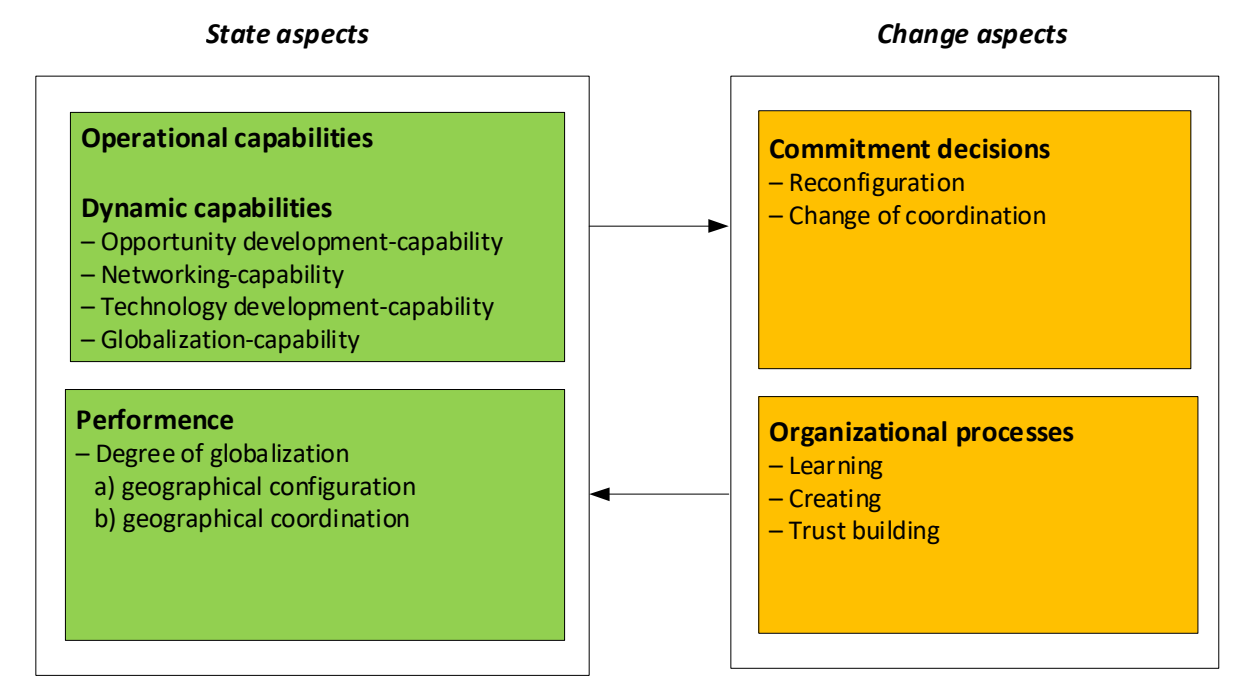

Figure 6. Second Globalisation Uppsala Model of 2014 Source: (Vahlne \& Ivarsson, 2014, p. 242).

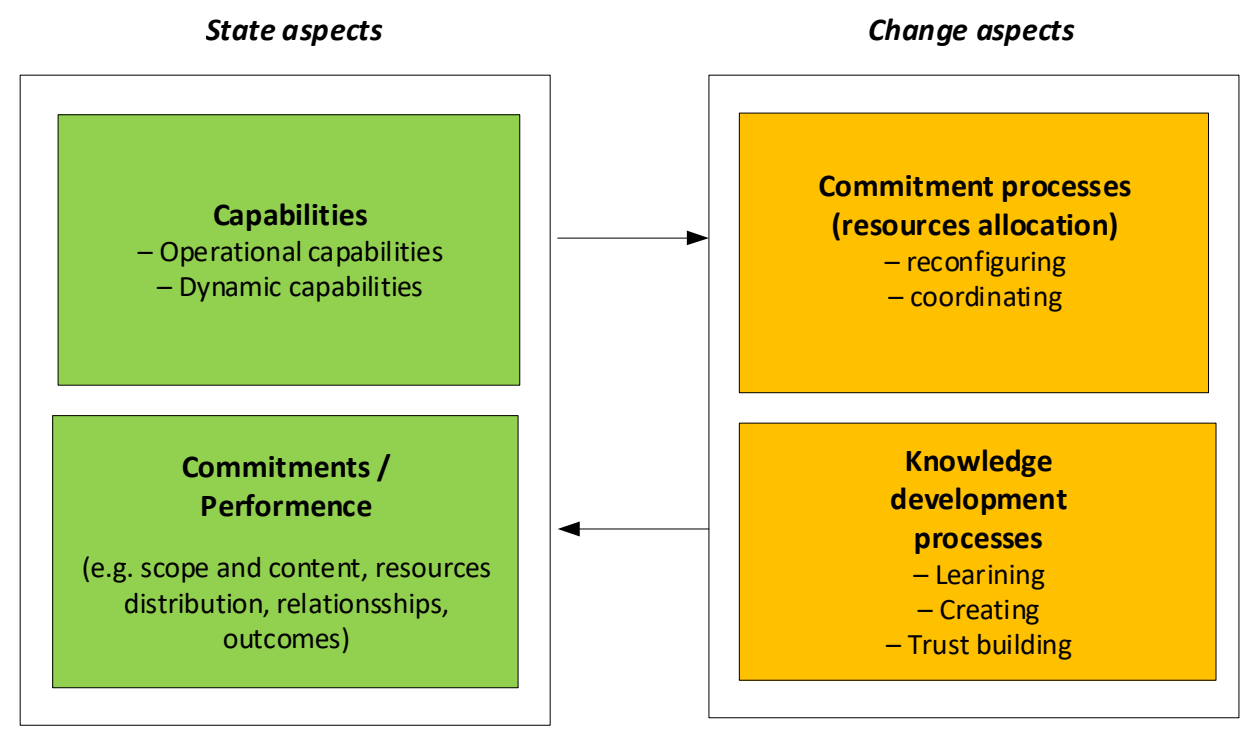

Figure 7. Second Multinational Uppsala Model of 2017

Source: developed, extended and adapted from (Vahlne \& Ivarsson, 2017, p. 1092).

The dynamic variables include commitment processes and knowledge development processes. The commitment process is based on reconfiguring and coordinating or resources (their allocation or withdrawal). Knowledge development processes include mainly learning, creating and trust building, but are met in both dimensions - inter- or intra-organizational ones. This variable contains also three entrepreneurial knowledge processes such as (i) relationship building, (ii) flexibility in strategy implementation, and (iii) adaptation to the competitive task environment. "The essence of the model is that resources commitment and the knowledge development processes are intertwined" (Vahlne \& Johanson, 2017, p. 1092). 


\section{DISCUSSION}

Stages models belong to the mainstream of internationalization theory and are most often used in empirical studies. However, they are not perfect concepts, which is almost as often taken up in the literature. The main criticism levelled at them concerns sequentiality. Not every firm has to go through all the stages, starting with the initial one and finishing with the last stage. There are also extreme opinions in the literature, such as Cavusgil's $(1994$, p. 18) the death of stages models, which was proclaimed in the context of the observed phenomenon of born globals in Australia. Nonetheless, the criticism of stages models includes the following controversy:

- not every firm goes through all the stages of the establishment chain, in practice there is leapfrogging of some stages (Cannon \& Willis, 1981),

- some firms use either the accelerated internationalization path (rapid internationalization), as is the case of hidden champions, some firms follow either an accelerated internationalization path or some firms are international or even global from the very beginning (born globals) (Oviatt \& McDougall 1994),

- stage models do not take into account either the strategic approach of the management or the entrepreneurial processes, which seem to be crucial for the international development of the firm - entrepreneurial internationalization (Turnbull, 1987; Andersson, 2000],

- due to the specific nature of services, stages models do not apply to the internationalization analysis of service firms (Grőnroos, 1999, p. 292).

Table 1. Summary of various modified Uppsala models

\begin{tabular}{|c|c|c|c|c|c|c|}
\hline 1977 & 2009 & 2010 & 2011 & 2013 & 2014 & 2017 \\
\hline \multicolumn{7}{|l|}{ Authors } \\
\hline $\begin{array}{l}\text { Johanson \& } \\
\text { Vahlne }\end{array}$ & $\begin{array}{l}\text { Johanson \& } \\
\text { Vahlne }\end{array}$ & $\begin{array}{l}\text { Schweizer, } \\
\text { Vahlne \& Jo- } \\
\text { hanson }\end{array}$ & $\begin{array}{l}\text { Vahlne, } \\
\text { Ivarsson \& Jo- } \\
\text { hanson }\end{array}$ & $\begin{array}{l}\text { Johanson \& } \\
\text { Vahlne }\end{array}$ & $\begin{array}{l}\text { Vahlne \& } \\
\text { Ivarsson }\end{array}$ & $\begin{array}{l}\text { Johanson \& } \\
\text { Vahlne }\end{array}$ \\
\hline \multicolumn{7}{|l|}{ Theoretical base } \\
\hline Stages model & $\begin{array}{l}\text { Network ap- } \\
\text { proach }\end{array}$ & $\begin{array}{l}\text { International } \\
\text { entrepreneur- } \\
\text { ship perspec- } \\
\text { tive }\end{array}$ & $\begin{array}{l}\text { International } \\
\text { entrepreneur- } \\
\text { ship and net- } \\
\text { work approach }\end{array}$ & $\begin{array}{l}\text { Dynamic ca- } \\
\text { pabilities and } \\
\text { network ap- } \\
\text { proach }\end{array}$ & $\begin{array}{l}\text { Dynamic capa- } \\
\text { bilities and } \\
\text { strategic ap- } \\
\text { proach }\end{array}$ & $\begin{array}{l}\text { Integrated ap- } \\
\text { proach }\end{array}$ \\
\hline \multicolumn{7}{|l|}{ Empirical base } \\
\hline 4 cases & 1 case & 3 cases & 1 case & none & 17 cases & 1 case \\
\hline \multicolumn{7}{|l|}{ State aspects } \\
\hline $\begin{array}{l}\text { Market } \\
\text { knowledge }\end{array}$ & $\begin{array}{l}\text { Knowledge op- } \\
\text { portunities }\end{array}$ & $\begin{array}{l}\text { Knowledge, } \\
\text { Opportunities, } \\
\text { Entrepreneur- } \\
\text { ial capabilities }\end{array}$ & $\begin{array}{l}\text { Knowledge op- } \\
\text { portunities }\end{array}$ & $\begin{array}{l}\text { Dynamic ca- } \\
\text { pabilities and } \\
\text { Operational } \\
\text { capabilities }\end{array}$ & $\begin{array}{l}\text { Operational } \\
\text { capability and } \\
\text { Dynamic capa- } \\
\text { bilities }\end{array}$ & Capabilities \\
\hline $\begin{array}{l}\text { Market com- } \\
\text { mitment }\end{array}$ & $\begin{array}{l}\text { Network posi- } \\
\text { tion }\end{array}$ & $\begin{array}{l}\text { Network posi- } \\
\text { tion }\end{array}$ & $\begin{array}{l}\text { Network posi- } \\
\text { tion (internally } \\
\text { and externally) }\end{array}$ & $\begin{array}{l}\text { Network posi- } \\
\text { tion (intra and } \\
\text { inter) }\end{array}$ & Performance & $\begin{array}{l}\text { Commitment / } \\
\text { Performance }\end{array}$ \\
\hline \multicolumn{7}{|l|}{ Change aspects } \\
\hline $\begin{array}{l}\text { Commitment } \\
\text { decisions }\end{array}$ & $\begin{array}{l}\text { Relationship } \\
\text { commitment } \\
\text { decisions }\end{array}$ & $\begin{array}{l}\text { Relationship } \\
\text { commitment } \\
\text { decisions }\end{array}$ & $\begin{array}{l}\text { Decisions to } \\
\text { reconfigure } \\
\text { and redesign } \\
\text { coordination } \\
\text { systems }\end{array}$ & $\begin{array}{l}\text { Commitment } \\
\text { decisions (re- } \\
\text { configuration } \\
\text { and coordina- } \\
\text { tion) }\end{array}$ & $\begin{array}{l}\text { Commitment } \\
\text { decisions (re- } \\
\text { configuration } \\
\text { and coordina- } \\
\text { tion) }\end{array}$ & $\begin{array}{l}\text { Commitment } \\
\text { processes }\end{array}$ \\
\hline $\begin{array}{l}\text { Current activi- } \\
\text { ties }\end{array}$ & $\begin{array}{l}\text { Learning, Cre- } \\
\text { ating, and } \\
\text { Trust building }\end{array}$ & $\begin{array}{l}\text { Learning, Cre- } \\
\text { ating, Trust } \\
\text { building, and } \\
\text { Exploiting con- } \\
\text { tingencies }\end{array}$ & $\begin{array}{l}\text { Learning, Cre- } \\
\text { ating, and } \\
\text { Trust building }\end{array}$ & $\begin{array}{l}\text { Learning, Cre- } \\
\text { ating, and } \\
\text { Trust building } \\
\text { (as inter-or- } \\
\text { ganizational } \\
\text { processes) }\end{array}$ & $\begin{array}{l}\text { Learning, Cre- } \\
\text { ating, and } \\
\text { Trust building } \\
\text { (as organiza- } \\
\text { tional pro- } \\
\text { cesses) }\end{array}$ & $\begin{array}{l}\text { Knowledge de- } \\
\text { velopment } \\
\text { processes } \\
\text { (Learning, Cre- } \\
\text { ating, and } \\
\text { Trust building) }\end{array}$ \\
\hline
\end{tabular}

\footnotetext{
Source: own compilation.
} 


\section{CONCLUSIONS}

The original version of the Uppsala model of 1977 has been revised at least six times (not counting some additional minor modifications). The first major modification occurred under the influence of the development of the network approach to the internationalization processes of firms, as a result of which the network Uppsala model was proposed in 2009. This model received the JIBS Decade Award for 2009-2019. With the emergence of international entrepreneurship (the late-1980s and mid-1990s) and the dynamic development of this concept (in the first decade of the 21st century), the entrepreneurial Uppsala model was proposed in 2010 as the second major revision of the original model. The third modification, which occurred in 2011, is the introduction of international network coordination into the model, i.e. the creation of the first, preliminary Uppsala model discussing the globalization processes. The year 2013 brought another revision of the model, this time, dynamic capabilities appeared, and the model explains the phenomenon of multinational enterprises and transnational corporations. Another revision of the model was published in 2014. It introduces the second globalization Uppsala model, built on all previous concepts and introduces the degree of globalization into the model as a result of the process of the firm-level internationalization. The most recent revision of the model was published in 2017, it organizes and integrates the previous outputs of the Uppsala models (Table 1).

Although stages models (mainly the Uppsala model) are often criticized in the literature, they are nevertheless still widely used in empirical research, and their successive modifications may attest to their universal character and timelessness. Hult, Gonzalez-Perez and Lagerström underscore that the Uppsala model "has served as a theoretical underpinning” (2020, p. 38). They see a lot of potential uses of these revised models, especially the one of 2017 in future international business research in such contexts as technological entrepreneurship or digitalization of global business. Last year, Vahlne and Johanson (2020, p. 4) concluded as follows:

"We suggest that our model can still be improved further by recognizing the general psychological characteristics of managers, for instance, what makes them tend to shy away from radical change and to prefer instead an incremental approach? What does this mean for internationalization?"

\section{REFERENCES}

Andersson, S. (2000). The internationalization of the firm from and entrepreneurial perspective. International Studies of Management \& Organization, 30(1), 63-93. https://doi.org/10.1080/00208825.2000.11656783

Cannon, T., \& Willis, M. (1981). The smaller firm in international trade. European Small Business Journal, 1(3), 45-55.

Cavusgil, S.T. (1994). Born globals: A quiet revolution among Australian exporters. Journal of International Marketing Research, 2(3), 4-6.

Coviello, N.E., \& McAuley A. (1999). Internationalisation and the smaller firm: A review of contemporary empirical research. Management International Review, 39(3), 223-256.

Crick, D., Chaudhry, Sh., \& Batstone, S. (2001). An investigation into the overseas expansion of small Asian-owned U.K. Firms. Small Business Economics, 16(2), 75-94.

Drew, N., \& Sarasvathy, S.D. (2002). What effectuation is not: Further development of an alternative to rational choice. Academy of Management Conference, Denver. Retrieved from http://www.effectuation.org/sites/default/files/noteffn.doc on 16 January 2021.

Forsgren, M. (2015). The Concept of Learning in the Uppsala Internationalization Process Model: A Critical Review. In: M. Forsgren, U. Holm, \& J. Johanson (Eds), Knowledge, Networks and Power. London: Palgrave Macmillan. https://doi.org/10.1057/9781137508829_4

Głodowska, A. (2019). Comparative International Entrepreneurship: Theoretical Framework and Research Development. Entrepreneurial Business and Economics Review, 7(2). https://doi.org/10.15678/EBER.2019.070213 
Głodowska, A., Maciejewski, M., \& Wach, K. (2019a). How Entrepreneurial Orientation Stimulates Different Types of Knowledge in the Internationalisation Process of Firms from Poland?. Entrepreneurial Business and Economics Review, 7(1), 61-73. https://doi.org/10.15678/EBER.2019.070104

Głodowska, A., Maciejewski, M., \& Wach, K. (2019b). Oddziaływanie orientacji przedsiębiorczej na wykorzystanie wiedzy w procesie umiędzynarodowienia na przykładzie firm z Polski (The Impact of Entrepreneurial Orientation on the Use of Knowledge in the Process of Internationalisation Based on the Example of Companies from Poland). Studies of the Industrial Geography Commission of the Polish Geographical Society, 33(1), 1835. https://doi.org/10.24917/20801653.331.2

Głodowska, A., Pera, B., \& Wach, K. (2016). The International Environment and Its Influence on the Entrepreneurial Internationalization of Firms: The Case of Polish Businesses. Problemy Zarzqdzania - Management Issues, 14(3), 107-130. https://doi.org/10.7172/1644-9584.62.7

Grőnroos, C. (1999). Internationalization strategies for services. Journal of Service Marketing, 13(4-5), $290-297$.

Hult, G.T.M., Gonzalez-Perez, M.A. \& Lagerström, K. (2020). The theoretical evolution and use of the Uppsala model of internationalization in the international business ecosystem. Journal of International Business Studies, 51(1), 38-49. https://doi.org/10.1057/s41267-019-00293-x

Johanson, J., \& Vahlne, J.-E. (1974). The internationalisation process of the firm. Mimeographed Working Paper. Uppsala: Department of Business Administration, University of Uppsala.

Johanson, J., \& Vahlne, J.-E. (1977). The internationalization process of the firm: A model of knowledge development and increasing foreign market commitments. Journal of International Business Studies, 8(1), $23-32$.

Johanson, J., \& Vahlne, J.-E. (1990). The mechanism of internationalisation. International Marketing Review, 7(4), 11-24. https://doi.org/10.1108/02651339010137414

Johanson, J., \& Vahlne, J.-E. (2003). Business relationship learning and commitment in the internationalisation process. Journal of International Entrepreneurship, 1(1), 83-101. https://doi.org/10.1023/A:1023219207042

Johanson, J., \& Vahlne, J.-E. (2006). Commitment and opportunity development in the internationalization process: A note on the Uppsala internationalization process model. Management International Review, 46(2), 1-14. https://doi.org/10.1007/s11575-006-0043-4

Johanson, J., \& Vahlne, J.-E. (2009). The Uppsala internationalization process model revisited: From liability of foreignness to liability of outsidership. Journal of International Business Studies, 40, 1411-1431. https://doi.org/10.1057/jibs.2009.24

Johanson, J., \& Wiedersheim-Paul, F. (1975). The internationalization of the firm: Four Swedish cases. Journal of Management Studies, 12(3), 305-322. https://doi.org/10.1111/j.1467-6486.1975.tb00514.x

Maciejewski, M., \& Wach, K. (2019). International Startups from Poland: Born Global or Born Regional?. Journal of Management and Business Administration Central Europe, 27(1), 60-83. https://doi.org/10.7206/jmba.ce.2450-7814.247

Mejri, K., \& Umemoto, K. (2010). Small- and medium-sized enterprise internationalization: Towards the knowledge-based model. Journal of International Entrepreneurship, 8(2), 156-167.

Morgan, R.E., \& Katsikeas, C.S. (1997). Theories of international trade, foreign direct investment and firm internationalization: A critique. Management Decision, 35(1), 68-78.

Oviatt, B.M., \& McDougall, P.P. (1994). Towards a theory of international new ventures. Journal of International Business Studies, 25(1), 45-64.

Pawęta, E. (2016). The Effectual Approach in Born Global Firms: Current State of Research. Entrepreneurial Business and Economics Review, 4(2), 105-115. https://doi.org/10.15678/EBER.2016.040209

Rundh, B. (2001). International market development: New patterns in SMEs international market behaviour? Market Intelligence \& Planning, 19(5), 319-329.

Ruzzier, M., Hisrich. R.D., \& Antoncic, B. (2006). SME internationalization research: Past, present, and future. Journal of Small Business and Enterprise Development, 13(4), 476-497. https://doi.org/10.1108/14626000610705705

Sarasvathy, S.D. (2001). Causation and effectuation: Towards a theoretical shift from economic inevitability to entrepreneurial contingency. Academy of Management Review, 26(1), 243-263. https://doi.org/10.2307/259121

Schweizer, R., Vahlne, J.-E., \& Johanson, J. (2010). Internationalization as an entrepreneurial process. Journal of International Entrepreneurship, 8(4), pp. 343-370. https://doi.org/10.1007/s10843-010-0064-8 
Schwens, Ch., Steinmetz, H., \& Kabst, R. (2010), Growth and internationalization: Renewable energy and new technology-based firms (pp. 113-123). In A. Gerybadze, U. Hommel, H.W. Reiners, D. Thomaschewski (Eds), Innovation and International Corporate Growth. Heidelberg-New York: Springer.

Turnbull, P.A. (1987). Challenge to stage theory of the internationalization process (pp. 21-40). In P.J. Rosson, S.D. Reid (Eds), Managing Export Entry and Expansion. New York, NY: Praeger.

Vahlne, J.-E., \& Ivarsson, I. (2014). The globalization of Swedish MNEs: Empirical evidence and theoretical explanations. Journal of International Business Studies, 45(3), 227-247.

Vahlne, J.-E., \& Johanson, J. (2012). New Technology, new environments and new internationalization process? In: V. Havila, M. Forsgren \& H. Håkansson (Eds), Critical perspectives on internationalisation (pp. 209-228). London: Pergamon.

Vahlne, J.-E., \& Johanson, J. (2013). The Uppsala model on evolution of the multinational business enterprise: From internationalization to coordination of networks. International Marketing Review, 30(3), 189-208. https://doi.org/10.1108/02651331311321963

Vahlne, J.-E., \& Johanson, J. (2017). From internationalization to evolution: The Uppsala model at 40 years. Journal of International Business Studies, 48(9), 1087-1102. https://doi.org/10.1057/s41267-017-0107-7

Vahlne, J.-E., \& Johanson, J. (2020). The Uppsala model: Networks and micro-foundations. Journal of International Business Studies, 51(1). https://doi.org/10.1057/s41267-019-00277-x

Vahlne, J.-E., Ivarsson, I., \& Johanson, J. (2011). The tortuous road to globalization for Volvo's heavy truck business: extending the scope of the Uppsala Model. International Business Review, 20(1), 1-14. https://doi.org/10.1016/j.ibusrev.2010.05.003

Vahlne, J.-E., Schweizer, R., \& Johanson, J. (2012). Overcoming the liability of outsidership - the challenge of HQ of the global firm. Journal of International Management, 18(3), 224-232. https://doi.org/10.1016/j.intman.2012.04.002

Verbeke, A. (2020). The JIBS 2019 Decade Award: The Uppsala internationalization process model revisited: From liability of foreignness to liability of outsidership. Journal of International Business Studies, 51(1), 1-3. https://doi.org/10.1057/s41267-019-00292-y

Wach, K. (2015a). Entrepreneurial Orientation and Business Internationalisation Process: The Theoretical Foundations of International Entrepreneurship. Entrepreneurial Business and Economics Review, 3(2), 9-24. https://doi.org/10.15678/EBER.2015.030202

Wach, K. (2015b). Entrepreneurship without Borders: Do Borders Matter for International Entrepreneurship. Problemy Zarzq̨dzania - Managmenet Issues, 14(1[2]), 82-92. http://dx.doi.org/10.7172/1644-9584.51.6

Wach, K. (2015c). Incremental versus Rapid Internationalisation of Firms: Results of Exploratory Investigation from Poland. Entrepreneurial Business and Economics Review, 3(4), 37-48. https://doi.org/10.15678/EBER.2015.030403

Wach, K. (2016a). Innovative Behaviour of High-Tech Internationalized Firms: Survey Results from Poland. Entrepreneurial Business and Economics Review, 4(3), 153-165. https://doi.org/10.15678/EBER.2016.040311

Wach, K. (2016b). Otoczenie międzynarodowe jako czynnik internacjonalizacji polskich przedsiębiorstw (International Environment as a Factor for Internationalisation of Polish Firms). Studies of the Industrial Geography Commission of the Polish Geographical Society, 30(1), 7-20. https://doi.org/10.24917/20801653.301.1

Wach, K. (2017). Ewolucja uppsalskiego modelu internacjonalizacji przedsiębiorstwa: w kierunku nielinearności procesu umiędzynarodowienia. International Entrepreneurship Review, 3(3), 159-170 (Special Issue: "Księga jubileuszowa dedykowana Profesorowi Stanisławowi Wydymusowi").

Wickham, P.A. (2006). Strategic entrepreneurship. 4th edition. Harlow: Prentice Hall.

Wickramasekera, R., \& Oczkowski, E. (2006). Stage models re-visited: A measure of the stage of internationalisation of a firm. Management International Review, 46(1), 39-55. https://doi.org/10.1007/s11575-007-0048-7 


\section{Author}

\section{Krzysztof Wach}

Full Professor at Cracow University of Economics (Poland). Professor of social sciences (2020), Habilitation (dr hab.) in economics (2013), PhD in management (2006), MSc in international economics (2001). His research interests include international business, international entrepreneurship, EU studies, entrepreneurship and innovation, family firms. Member of AIB (Academy of International Business) and EIBA (European International Business Academy). Editor-in-Chief of 'Entrepreneurial Business and Economics Review' (Scopus, ESCI WoS). Associate Editor of various journals incl. 'European Journal of International Management' (SCI WoS), 'Central European Management Journal' (Scopus, ESCI WoS), 'Agris on-line Papers in Economics and Informatics' (Scopus) or 'European Integration Studies' (ESCI WoS). Member of the Committee for Economic Sciences of Polish Academy of Sciences (since 2020). Served as expert on entrepreneurship for the European Commission and OECD (2012-2019).

Correspondence to: Prof. Krzysztof Wach, PhD, Cracow University of Economics, ul. Rakowicka 27, 31-510 Kraków, Poland, e-mail: wachk@uek.krakow.pl

ORCID (i) http://orcid.org/0000-0001-7542-2863

\section{Acknowledgements and Financial Disclosure}

This publication was co-financed from the subsidy granted to Cracow University of Economics from the Ministry of Education and Science.

\section{Conflict of Interest}

The author declares that the research was conducted in the absence of any commercial or financial relationships that could be construed as a potential conflict of interest.

\section{Copyright and License}

This article is published under the terms of the Creative Commons

Attribution - NoDerivs (CC BY-ND 4.0) License

http://creativecommons.org/licenses/by-nd/4.0/ 
